\title{
OPERATION VALHALLA
}

a Cultural Politics book

A series edited by John Armitage,

Ryan Bishop, and Douglas Kellner 
FRIEDRICH KITTLER 


\section{OPERATION}

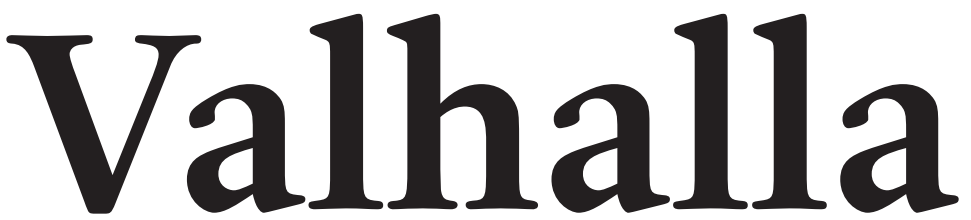

WRITINGS ON WAR, WEAPONS, AND MEDIA

EDITED AND TRANSLATED

BY ILINCA IURASCU,

GEOFFREY WINTHROP-YOUNG,

AND MICHAEL WUTZ

WITH AN INTRODUCTION BY

GEOFFREY WINTHROP-YOUNG 
(C) 202I Duke University Press

All rights reserved

Printed in the United States of America on acid-free paper $\infty$

Designed by Amy Ruth Buchanan

Typeset in Monotype Dante by Westchester Publishing Services

Project editor: Lisa Lawley

Library of Congress Cataloging-in-Publication Data

Names: Kittler, Friedrich A., author. | Winthrop-Young, Geoffrey, [date] editor. | Wutz, Michael, editor. | Iurascu, Ilinca, editor, translator.

Title: Operation Valhalla : writings on war, weapons, and media / Friedrich Kittler ; edited and translated by Ilinca Iurascu, Geoffrey Winthrop-Young, and Michael Wutz.

Description: Durham : Duke University Press, 202I. | Includes index. Identifiers: LCCN 2020022635 (print)

LCCN 2020022636 (ebook)

ISBN 978I4780I0715 (hardcover)

ISBN 978I4780II842 (paperback)

ISBN 978I4780I3I8I (ebook)

Subjects: LCSH: Communication and technology_-Philosophy. |

Literature-History and criticism. | Technology—Social aspects-

Philosophy. | War (Philosophy) | Weapons-Philosophy.

Classification: LCC P96.T42 K588 202I (print) | LCC P96.T42 (ebook) | DDC $302.23-\mathrm{dc} 23$

LC record available at https://1ccn.loc.gov/2020022635

LC ebook record available at https: / / lccn.loc.gov/2020022636

Cover art: Joseph G. Cruz, What happens when the horizon completes its circle, 20I6. Sand from the original test site of the V2, dimensions variable. From the installation titled Across the Sky, Came a Screaming, Evanston Art Center, Evanston, IL. Courtesy of the artist. 